\title{
The Political State Convention
}

The essentially distinctive thing in our government is the political convention. Representative assemblies may be traced to other times, and are to be found in many other lands and among various races. The elective franchise is not peculiarly ours. But the political party convention formulating a platform of principles, and nominating candidates for elective offices has been developed by circumstances and ideas of government distinctly our own. . .

The situation in Iowa differs from that of many states by reason of the fact that neither any one locality, nor any one interest, predominates in strength or influence. Rings and bosses have not, therefore, the means of securing continued supremacy which they find in some of our sister states. There is no one interest or combination of interests which can boldly demand that those who are in politics shall be for it in order to receive its support, or against it and take the consequences. . .

Taken as a whole, the delegates to a state convention quite fully and adequately represent the body of the voters who have been in the habit of supporting that particular party; for they are almost entirely taken from the body of a county convention, delegates to which have been selected by party caucuses in precincts. . I In most cases the interest of the candidate and of the local managers is to have a fairly decent, intelligent and influential body of men as representing the county in the state convention. . .

The party convention system has the weaknesses of popular government. Its result is not always the selection of the very best men, but rather the choosing for office of average men against whom no serious charges can be made. No portion of the machinery of government under any system is perfect, and the convention system is perhaps as little open to just com- 
plaint as any of the institutions under which we live. -Judge Emlin McClain in Midland Monthly, December, 1898.

\section{Forerunners of Official Register}

Nearly everyone conversant with Iowa state officials of the past recalls that William $\mathrm{H}$. Fleming was the private secretary of seven governors, and a well-informed man on Iowa history. But now, few know that he also served as deputy secretary of state under Gen. Ed Wright, who entered upon his duties January 2, 1867.

In Mr. Fleming's "Autobiography of a Private Secretary," AnNals of IowA, Vol. XV, p. 11, is related that then for the first time under state authority, information in regard to former state and territorial officers, legislators and judges was assembled and printed officially, such data having previously appeared in a private publication termed a State Almanac and issued in 1860 , by Richard Sylvester, at Iowa City, and Theodore Eagal; of Davenport.

Information of this character officially compiled and published for general distribution by the state, first appeared in the state census report, on suggestion of the Census Board, now known as the Executive Council, whose responsibility it was to take the state census until it was discontinued during Gov. Dan W. Turner's administration.

In 1886, Frank D. Jackson, secretary of state, issued the first compilation of the state Official Register, the publication of which has since continued, and now is compiled by the superintendent of printing.

\section{The Functions of Government}

Pres. Grover Cleveland: The lessons of paternalism ought to be unlearned and the better lesson taught that, while the people should patriotically and cheerfully support their government, its functions do not include the support of the people. 
Copyright of Annals of Iowa is the property of State of Iowa, by \& through the State Historical Society of Iowa and its content may not be copied or emailed to multiple sites or posted to a listserv without the copyright holder's express written permission. However, users may print, download, or email articles for individual use. 